\title{
How do "imagined farmers" negotiate actual risks? Biosafety trade-offs in Bt cotton production in Andhra Pradesh, India
}

\author{
Julia Freeman $^{1}$ \\ University of British Columbia, Canada
}

\section{Introduction}

India's encounter with Bt cotton - the country's first genetically engineered crop - has been highly contested and has rarely conformed to expectations. Particular efforts have been made to position and represent India's millions of cotton farmers within the debate over agricultural biotechnology, either by holding up their now widespread use of Bt cotton as an endorsement of the technology, or by using it as evidence of farmers' exploitation by multinational biotech corporations. While pro- and anti-agricultural biotechnology advocates leverage their claims against what will really benefit cotton farmers in India, farmers' own perspectives and priorities are often missing from the debate.

As with agricultural technologies generally, genetically engineered (GE) seed calls attention to the trade-offs being made between risks and benefits, although in this particular case the contest over who is making these trade-offs remains very much in flux. This article critically engages both pro- and anti- $\mathrm{Bt}$ cotton paradigms, and finds that in both cases the misconstrual or re-imaging of farmers' priorities and a narrow concept of "biosafety" (that is, the safety of human health and the environment) has hampered our understanding of what is at stake and what these trade-offs really cost. I introduce a broader risk framework as articulated by $\mathrm{Bt}$ cotton farmers in Andhra Pradesh, and argue that this case provides a compelling example of how political debate over GE farming can actually work to overshadow and redirect significant human and ecological implications of its use.

To address the gap of farmers' perspectives and priorities, I conducted interviews with small, medium, and large-scale cotton farmers in Andhra Pradesh. Analysis points to a number of significant unintended effects stemming from the use of Bt cotton, and highlights some important debates that are currently missing from the public discussion on agricultural biotechnology. Limitations of what I identify as a "biosafe use" paradigm advanced by Bt's cotton's supporters are identified, as it fails to reflect current working agricultural practices at the local level. This article also challenges the developmentalist tendency to stress crop yield as the motivator for using agri-biotech, by calling attention to how farmers consistently report that a reduction in pesticide usage is another important factor in their decision-making. And finally, this work questions civil society's sound rejection of agricultural biotechnology on the ground that it presents "inherent problems", while remaining oddly quiet on the question of the calamitous effects of heavy pesticide use for farmers.

\section{2. "There is no person in this village without $\mathrm{Bt} "$ : research methods and context}

This article examines how farmers regard Bt cotton, India's controversial, first and only commercialized genetically engineered crop. It also investigates the vantage points from which farmers' engagement with Bt cotton have been taken up and too often misconstrued. Bt cotton contains genetic material from the soil bacterium Bacillus thuringiensis in order to lend the hybrids an increased capacity to resist certain (Lepidopteran) pests. I employ a data set of ten interviews in seven villages in the Guntur and Warangal districts of Andhra Pradesh (Figure 1), an important cotton-producing state, with more than 1.65 million hectares planted, or 18\% of the national total (Clive 2010). Interviews with cotton farmers were carried out between April and May 2009. ${ }^{2}$ Though the interviews varied as to number of participants (sometimes conducted with small groups, other times with a single participant), all were semi-structured and approximately one hour long. The interviews consisted of two broad sets of questions. The first was organized around agronomic practices whereby farmers detailed their available land and specific growing conditions, crops grown, length of time they have been growing Bt cotton, any major pest attacks, and where they procured their seed. The second part of the interview focused on the perceived risks and benefits of working with biotech seed by inquiring as to any current and specific concerns around Bt cotton, any changes noted since using Bt seed (in terms of pests, crop yields, and chemical inputs), their reasons for using Bt

\footnotetext{
1 Julia Freeman, PhD candidate, Institute for Resources, Environment and Sustainability, University of British Columbia, Canada. Email: julya "at" interchange.ubc.ca. Thanks go to Dr. Ramesh Babu Para, Sri Srinivasa Reddy and Sri Vamshi Krishna for their assistance in the field. My gratitude is also extended to Drs. Terre Satterfield and Milind Kandlikar for their comments on an earlier version of the article, while any errors or shortcomings of this work remain my own. And special thanks are extended to the farmers who kindly agreed to participate in this study. The Social Science and Humanities Research Council of Canada (SSHRC) and University of British Columbia supported the research underpinning this article with fellowship and grant funding. This paper appears in a JPE Special Section of Eric Wolf Prize papers edited by Joe Heyman.

2 These interviews made up a portion of a larger field research involving preliminary fieldwork from December 2007 to January 2008, and a second phase between February and May 2009.
} 
cotton, and any expectations for the technology more generally. Interviews were analyzed using Excel and Atlas.ti qualitative data software.

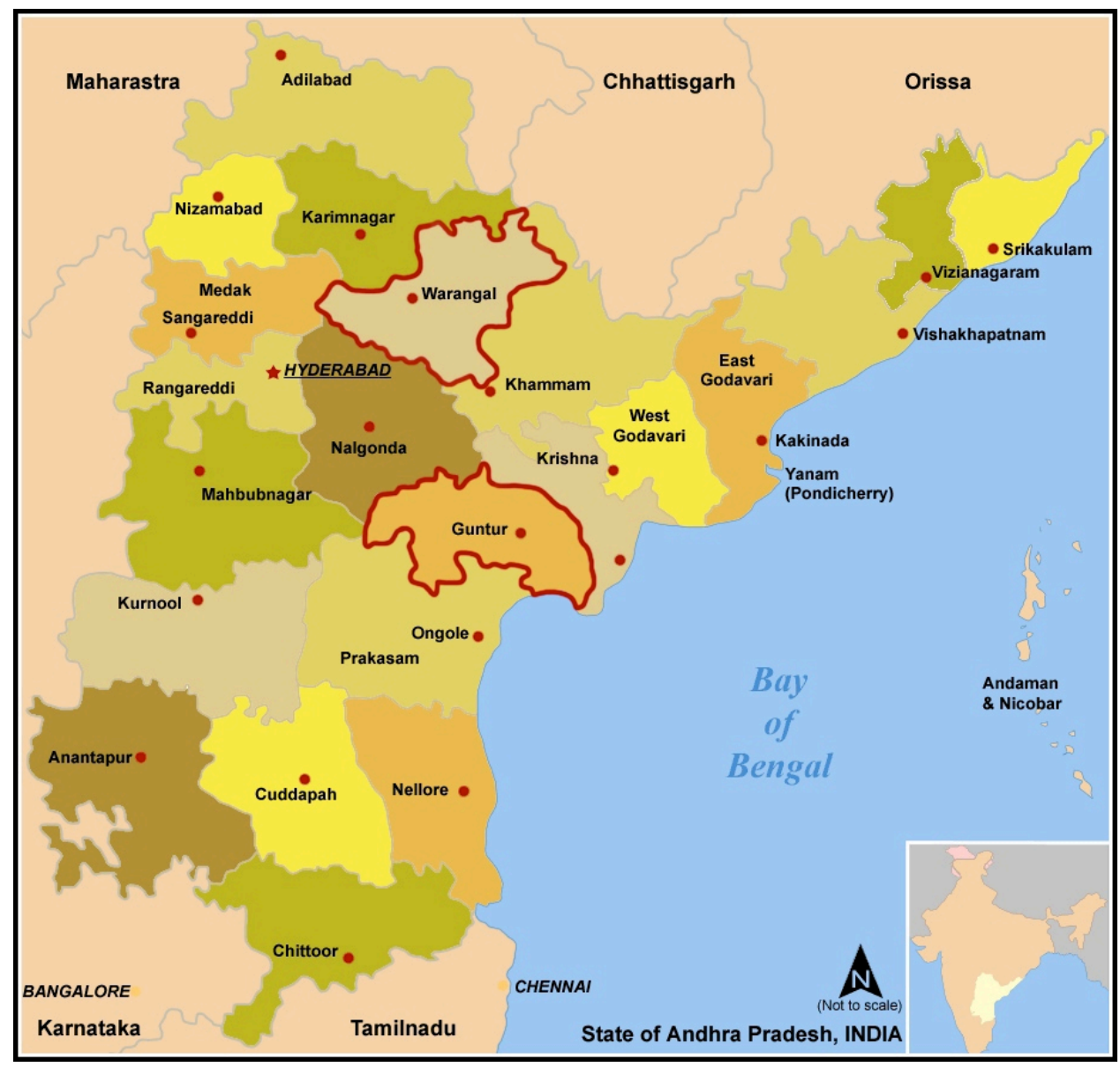

Figure 1: Map of Guntur and Warangal districts in Andhra Pradesh, India. ${ }^{3}$

Research participants were sampled opportunistically; and it should be noted that specific villages are represented here with pseudonyms. Andhra Pradesh and the district of Warangal in particular are established in the literature as significant cotton-producing regions for the nation (Qayum and Sakkhari 2002; Stone 2007; Herring 2008). The district of Guntur provides an interesting comparison, as farmers there grow chili alongside cotton as an alternative cash crop (Sri, Rao, Sekhar and Chalam 2010). There was an earlier adoption of GE seed in Warangal, with farmers in the villages of Raseetha and Penthapali starting as early as 2002, which was the first year of commercialization. I have classified "small-scale" farmers as those working with one to four acres of land, "medium-scale" farmers with five to nine acres, and "large-scale" farmers with ten acres and above. The opportunistic nature of the sampling meant that a larger proportion of what I classify as "large-scale" farmers are represented. It should be noted that no farmers worked more than 18 acres of land and that these large holdings were leased, rather than owned. One benefit of a larger sample of "large-scale" farmers is that it helped call attention to certain impacts of Bt cotton on hired labor, as smallscale farmers tend to hire fewer laborers and distribute work among family members whenever possible. Furthermore, all participants may be considered marginal producers when considered in the light of global industrial cotton production (where by cotton is grown on farms measured in the hundreds of acres in the United States, for example). ${ }^{4}$

\footnotetext{
3 Adapted from Miljoshi's map of AP districts, under the Creative Commons Attribution-Share Alike 2.5 Generic, 2.0 Generic and 1.0 Generic license, available at: http://commons.wikimedia.org/wiki/File:Map_AP_dist_all_shaded.png. [Accessed July 7 2012]. This work is likewise licensed under the Creative Commons Attribution 3.0 Unported License. To view a copy of this license, visit http://creativecommons.org/licenses/by/3.0/ or send a letter to Creative Commons, 444 Castro Street, Suite 900, Mountain View, California, 94041, USA.

4 For additional information regarding the characteristics of U.S. industrial cotton farming, please see: http://www.ers.usda.gov/publications/sb974-2/sb974-2.pdf [Accessed May 1 2011]
} 
Agricultural biotechnology has sparked controversy around the world for a host of reasons, from questions of how to regulate it, to discussions regarding the ethics of its application (Jasanoff 2005; Carr and Levidow 2000). Points of dispute in northern states have often focused on scientific uncertainties regarding potential medium and long-term health and environmental risks of GE, as well as the extent to which the technology advances corporate power through patenting of the food chain (Bernauer 2003). The risks of GE farming in India have been debated both along social and ecological lines. Controversy over Bt cotton began in Andhra Pradesh after a tragic spate of farmer suicides (Stone 2002), blamed by some on what has been called the "failure" of Bt cotton crops (Sahai 2005; Herring 2007). To critics, these deaths represented the risks of increasing rural poverty and farmer indebtedness having purchased high-tech seed. Later, a series of mysterious livestock deaths were alleged (if unfounded) to be tied to the animals' grazing in Bt fields and helped launch the region into international biotechnology debates (Rao 2007). Again, critics decried Bt cotton for presenting environmental questions poorly understood by science.

The controversy over biotechnology in India meant that my interviews took place in a social environment marked by division, though not within the villages particularly. Rather, divisions between the proponents and critics of $\mathrm{Bt}$ cotton are entrenched in seemingly perpetual debates about Bt cotton's efficaciousness (Herring 2009) and a fetishized concern with proving or contesting its yield increases, as though the numbers might hold the power to persuade all skeptics. There are divisions over GE policy, including the regulatory failure to safely release the first Bt cotton hybrids in India (Herring 2007), and civil society's successful blocking of the release of Bt brinjal (aubergine) in 2009, which was slated to be India's first genetically engineered food crop (Sharma 2010). There have been tussles over the name of India's biotech regulatory body - recently changed from the Genetic Engineering Approval Committee, with its ring of accommodation, to a more rigorous-sounding Genetic Engineering Appraisal Committee (GEAC). ${ }^{5}$ And there is the suggestion of division yet to come, as a long awaited Bill to transform the structure of the regulatory regime remains hotly contested (Sengupta 2011). What concerns us here, however, is the remarkable gap between those national or international debates regarding the risks that Bt cotton presents to these farmers, and the very different sites of risk articulated by the farmers themselves.

\section{3. "Imagined farmers" and established crops}

Political ecologist Raymond Bryant argued a decade ago that "the interaction between environmental and political forces will mediate Third World development in unprecedented ways" (Bryant 1992: 12). This has certainly proven to be the case for the conflicts and negotiations over agricultural biotechnology. From local Indian non-governmental organizations (NGOs) to transnational organizations, people opposing to the use of GE seed can be found at every level, as can others who are working to improve biotech regulations or develop new transgenic crops. Most of these people, whether supporters or opponents of agri-biotech, enjoy the privileges of urban life and education. Meanwhile, both the use and the eschewal of Bt crops is having important health and environmental impacts for marginal farmers and the direction of future agricultural development in India. Thus the jockeying to speak on behalf of the more than six million Bt cotton producers nationwide (Clive 2010) is an increasingly charged political act. This article seeks to problematize these representations in the spirit of what Nick Rose has called the "...the contestability of regimes of authority that seek to govern us in the name of our own good" (Rose 1999: 59).

Much like Ryan Galt's work with Costa Rican farmers and the regulatory risks they face, this article identifies two broad political positions taken up in the Bt cotton risk debate. Galt identifies the agrochemical industry position, first dubbed the "safe use" paradigm by Murray (1994) which assumes pesticide usage to be a vital - if hazardous - dimension of productive farming; and advances training and information to ameliorate conditions for the use of pesticides in the global South (Galt 2007: 389). This argument applies similarly to Bt cotton, in what we might consider the "biosafe use" criteria that industry and regulators espouse, whereby agricultural biotechnology's risks are posited as worthwhile and negotiable with the right training and knowledge. Likewise, Galt identifies an "inherent problems" paradigm that argues pesticide usage is intrinsically dubious given basic features of the technology itself and the consistent lack of caution with which pesticides are used. In explaining the position of his own work, which conforms to neither camp, Galt writes that "...explaining farmers' caution with pesticides is not to downplay pesticides' many negative effects or to paint a rosy picture about chemically-dependent agriculture, but is instead to acknowledge that farmers can effectively respond to regulation to tackle some pesticide problems" (Galt 2007: 389). Similarly, this article would suggest that somewhere between the "biosafe use" and "inherent problems" of GE paradigms, there are millions of Indian farmers who are navigating risks and regulations in ways that warrant a closer look. These navigations reveal a rationality in farmers' land management (Blaikie and Brookfield 1987) and can help to unpack the motives for, and impacts of Bt cotton use in India.

Informing this effort is Gupta's acclaimed work in rural Northern India as he reconciles so-called "indigenous knowledges" with "modern" farming technologies and the complex hybrid practices that emerge from this (Gupta 1998). This work gives "substance to the interrelationships between humoral theories of agronomy, local politics, and the development-oriented institutions and policies of the nation-state" (Gupta

\footnotetext{
${ }^{5}$ http://www.moef.nic.in/divisions/csurv/geac/613.pdf
} 
1998: 226). ${ }^{6}$ Gupta, for instance, identifies the importance of both the Vedas and the Green Revolution in the agricultural development of the village. ${ }^{7}$ Tellingly, this nuanced hybridity becomes increasingly elusive as Gupta's focus moves from farmers and their practices, to their leaders engaging global environmental movements - some of whom would later become rather well known for anti-GE activism in India (e.g. Nanjundaswamy's Operation Cremate Monsanto). At the end of the twentieth century, important farmers' associations were involved in anti-globalization campaigns that resonated with India's earlier nationalist struggle (Gupta 1998: 322) as evidenced in the campaign to have biotech giant Monsanto "Quit India" just as India had once mobilized against British colonial rule. Global capitalism, as epitomized by transnational corporations like Monsanto, is "a powerful source of environmental change" (Bryant 1992: 20), and in this case Monsanto did not in fact Quit India. A decade later, Monsanto's Cry 1Ac and Cry2Ab genes constitute the lion's share of the patented genes in Bt cotton hybrids that have been only increasingly taken up around the country. But they have been taken up, I would suggest, with dexterity and hybrid learning comparable to that noted by Gupta in the adoption of Green Revolution technologies before them.

The Indian context provides a lively example of where agri-biotech policies can be analyzed as the result of an active "...struggle between competing actors..." seeking to shape their own governance (Bryant 1992: 18). With this in mind, in the next section I address the decreased use of pesticides that has accompanied the rush for Bt cotton, a transformation with its own important ecological, political and health effects.

\section{Pesticide problems and the GE debate}

Currently, India is the largest producer of pesticides in Asia and ranks twelfth in the world for the use of pesticides (Abhilash and Singh 2009: 1). The risks of pesticide usage are myriad, and are fruitfully disaggregated for analytic purposes; they may include health effects, environmental impacts, and regulatory risks to those who apply them, as well as risks to others who may consume pesticide residues on food crops (Galt 2007: 370). ${ }^{8}$ Given the widely agrarian nature of Indian society, large numbers of people are hence exposed to a range of chemicals used to control insect populations, weeds and fungi, although the use of pesticides is not evenly distributed around the country. Pesticides are chiefly used on commercial crops, and it has been reported that, "cotton cultivation alone uses more than $60 \%$ of the national consumption." (Mancini, Van Bruggen, Jiggins, Ambatipudi and Murphy 2005: 221). Recent news put the expenditures for pesticides employed in cotton production at 3.8 billion rupees (US\$683m), that is nearly half of the market in 2011, valued at around 8 billion (US\$143.8m) (Koshy 2011). Cotton farmers have relied heavily on insecticides since shifting from desi (traditional) seed varieties to higher yielding hybrids in the 1980s. In fact, since that time pesticides have accounted for $40-50 \%$ of the cost of producing cotton (Abhilash and Singh 2009: 4). The crop is under threat from a range of different pests, but the bollworm is largely considered the most harmful, as it has been known to reduce cotton yields by $60-80 \%$ and lead to approximately one billion dollars (55,625 billion rupees) worth of crop loss per year (Gujar 2001).

Integrated Pest Management (IPM) "is a complex, knowledge-based technology that combines biological, cultural and chemical control" in order to rein in the use of pesticides while managing pest populations at levels that do not harm the economic viability of a crop (Mancini 2006: 27). This technology is largely credited with helping reduce pesticide usage from its peak in early 1990s (at around 75,000 metric tons of active ingredient) (SEEP 2010:1). ${ }^{9}$ It is also known for being a labor-intensive approach to pest management, routinely involving manual checking of fields for pests among other techniques. Moreover, IPM as a management strategy does not preclude the use of Bt cotton, nor GE crops generally (Naranjo et al. 2008: 163).

Nevertheless, many farmers have relied on (and even overused) pesticides in order to combat cotton's pests, like the bollworm (Shetty 2004: 5264). On more than one occasion during my research, with a memory-rich and palpable dread, cotton farmers described the discovery of a bollworm infestation and how a crop could be ruined virtually overnight. Given the small plots of land many of the interview participants were working with, and the important role cotton plays as a source of cash for their households, such narratives helped to orient me to the narrow agro-ecological options available to farmers and why they might adopt heavy pesticide usage despite its well-known health, economic and environmental costs.

Within the districts of Guntur and Warangal, jassid, whitefly, and a variety of bollworms are all

\footnotetext{
${ }^{6}$ Gupta describes the humoral elements identified by farmers as hot and cold, dry and wet (Gupta 1998: 182).

7 The Vedas are an ancient body of sacred Hindu writing.

8 Regulatory risk has been defined as the "...possibility that an actor's behavior will be subject to state regulation and that out of compliance behavior will result in negative consequences that impact the actor" (Galt 2007: 379).

9 The role of pesticide policies and regulations is also of critical importance in accounting for this reduction, as India's government banned the use of hexachlorocyclohexane (BHC) in 1997, which had accounted for approximately 30\% of total pesticide consumption (SEEP 2010: 4).
} 
significant pests. ${ }^{10}$ The "indiscriminate use" of synthetic chemicals in pest control has also harmed "the natural enemies of pests", leading to growing difficulties in controlling pest populations (Shetty 2004: 5262$3)$. While in these districts approximately fifteen sessions for pesticide application is the optimum level to control cotton pests over a growing season, recent research has found that in Warangal this has risen to twenty or even thirty applications (Shetty 2004: 5263). This also renders the work more dangerous to farmers' health, and the crop less profitable. It has also been found that up to $47 \%$ of the farmers in the state of Andhra Pradesh purchased their pesticides on credit; they are then often compelled to sell their harvest back to the traders and moneylenders that financed them (Shetty 2004: 5265). Such transactions disadvantage farmers, but they often do not have the time (to remain in debt) or the storage capacities to hold on to their crops until the Government establishes a (higher) minimum support price later in the season.

In my first of three interviews in the village of Juradi, one participant described how prior to growing $\mathrm{Bt}$ cotton, he would have to spray as many as twenty times in a season for as many as seven to fifteen days in a row. However, since the shift to Bt cotton, he sprays one time about a month after planting, again at sixty days, and a final time around 120 days, with the arrival of "crop time." This new spraying standard of "three to four times per crop" came up again and again in farmer interviews, and appears to be the new operating standard not just in Guntur's villages but those of Warangal district as well. These findings correspond with other research reporting that Bt cotton receives fewer pesticides than its conventional predecessors (Kleter et al. 2007: 1111; Stone 2011: 395). Table 1 provides information about the participants and certain affected agricultural practices.

\begin{tabular}{|l|l|l|l|l|l|l|l|}
\hline Village & District & $\begin{array}{l}\text { \# of } \\
\text { Particip- } \\
\text { ants }\end{array}$ & $\begin{array}{l}\text { Landholdings } \\
\text { (acres) }\end{array}$ & $\begin{array}{l}\text { Started } \\
\text { growing Bt }\end{array}$ & $\begin{array}{l}\text { Yields } \\
\text { with Bt } \\
\text { (Quintals } \\
\text { per } \\
\text { acre) }\end{array}$ & $\begin{array}{l}\text { Applications } \\
\text { of pesticide } \\
\text { (current) }\end{array}$ & $\begin{array}{l}\text { Plant } \\
\text { Non-Bt } \\
\text { Refuge? }\end{array}$ \\
\hline Raseetha (1) & Warangal & 3 & $7-10$ & 2002 & $15-16$ & N/A** & No \\
\hline Raseetha (2) & Warangal & 2 & $10-18$ & 2004 & 10 & $3-5$ & No \\
\hline Garampet & Warangal & 1 & 5 & 2007 & $10-12$ & 3 & No \\
\hline Penthapali & Warangal & 7 & $2-4$ & 2002 & $15-18$ & $1-2$ & No \\
\hline Bhirgarty & Warangal & 4 & $6-10$ & 2003 & $15-20^{*}$ & $5-6$ & No \\
\hline Damalapudi & Guntur & 3 & $1-5$ & 2007 & N/A** & $2-4$ & No \\
\hline Juradi (1) & Guntur & 7 & $3-10$ & 2007 & $8-12$ & $3-4$ & No \\
\hline Juradi (2) & Guntur & 1 & 2 & 2007 & 20 & 3 & No \\
\hline Juradi (3) & Guntur & 2 & $3 /$ landless & 2006 & 10 & $2-3$ & No \\
\hline Madura & Guntur & 3 & $1-4$ & 2007 & 20 & $2-3$ & No \\
\hline
\end{tabular}

*One farmer reported yields up to 25 quintals per acre on one occasion.

**Responses were not provided for these questions.

\section{Table 1: Farmer interview specifics}

The reduction in application of pesticides from an optimum of fifteen sprays (or in excess of this) to an average of three to four sprays also helps limit the impacts of synthetic chemical use in agriculture. ${ }^{12}$ The development of resistance to these products is of particular concern, and the complex of pests has been undergoing considerable change since the use of cotton hybrids over desi varietals ${ }^{13}$ became widespread 30 years ago (Shetty 2004: 5262). Since that time, the technology itself has been transformed, and while a decade previously, farmers used a higher-volume and lower cost pesticide, current products on the market are sold in lower volumes at higher prices (because they are more highly concentrated). As an NGO staff member in the region explained, farmers "just need to spray 60ml per acre when they used to go for one liter". This trade-off between higher toxicity in pesticides and their dramatically reduced usage signals another category of concern: health effects associated with pesticides, and how these affect the use of genetically engineered cotton.

\footnotetext{
10 Common in the region: Jassid (Amrasca devastans); Whitefly (Bemisia tabaci); Pink bollworm (Pectinophora gossypiella); American bollworm (Helicoverpa armigera); Spotted bollworm (Earias vitella); Army bollworm (Spodoptera litura) (Rana 2010, ch3).

11 One quintal is equal to one hundred kilograms.

12 More precisely, an average of 2.6 to 3.6 applications, rounded up.

13 Varietals can be distinguished from hybrid plants in that hybrids, through controlled cross-pollination, demonstrate greater desired characteristics ("hybrid vigor") but must be cross-pollinated afresh each generation to do so. In the case of Bt cotton, hybrid seeds are therefore purchased each year. Varietals, if less productive, remain conducive to seed-saving and replanting in future years.
} 
Rashes, headaches, and nausea were listed by a farmer from Penthapali as regular occurrences while farming conventional cotton. Each is a well-known symptom stemming from acute toxicity due to contact with chemicals and contaminated farmlands (Bag 2000). These effects are not only felt by the (usually male) farmer who applies the pesticides, but also the (usually women) farmers/hired laborers who dilute the chemicals with water and fill the spray tanks. Women are also exposed by working in recently sprayed fields for harvest or other routine work. ${ }^{14}$ Moreover, most of the suggested protective measures are not adopted. Protective gear is considered hot and cumbersome, and many men spray without the use of gloves, shoes or a cloth to cover their mouths, despite working in these fields for three or four hours at a time. Research has found that farmers are generally aware of their risk of exposure as a result of these practices, but safety training rarely changes their day to day actions (Mancini et al. 2005: 212).

Reduced pesticide costs and exposure benefit the most marginal farmers in Andhra Pradesh because they have the most the gain. Malnutrition or other co-present medical conditions make such populations especially vulnerable to poisoning; while poverty makes them most likely to be applying the pesticides in the first place (wealthier farmers with greater land holdings hire laborers for such tasks) (Mancini et al. 2005: 222). However as we will see below, the pesticide problem of is in fact a shadow-side of the GE debate in India. GE seed is generally contested on rather different grounds. Nevertheless, this shadow-side is clearly implicit in farmer decision-making, even as it remains rarely articulated by civil society.

\section{The contested merits of Bt cotton}

India's civil society has raised concerns regarding agri-biotech and these have shifted over time, reflecting a changing policy landscape and the increasing uptake of Bt cotton by farmers over the past decade. Initial apprehension (prior to the commercialization of Bt cotton in 2001) focused on the place of large multinational corporations in Indian agriculture, and the loss of farmer autonomy to produce their own seed (Shiva, Emani and Jafri 1999; Shiva 2000). In the case of cotton, farmers already had more than 20 years of experience purchasing hybrid seed rather than producing and saving their own desi varietals, a factor that GE opponents may well have initially disregarded.

Environmental risks, such as the potential out-crossing of transgenes, insect resistance to the Bt toxin ${ }^{15}$ or its impact on local grazing animals, became the next wave of concern. This began with controversial news that farmers in the state of Gujarat were growing Bt cotton before regulators had approved the technology (Herring 2007) and that even after its commercialization, farmers all over the country were rejecting the recommended biosafety practice of planting $20 \%$ of their cotton fields with a non-Bt cotton refuge as the border, in favor of growing as much Bt cotton as their lands allow. The confusion over authorized seed and their quality at this time lead some critics to assert that Bt cotton had "failed" (RFSTE 2002; Special Correspondent 2003) and spurious seed sought legitimacy in the market by implying Bt genes - (e.g. calling itself the "BesT"). During my field research in 2009, seed packaging by well-established companies such as Nuziveedu with regulatory approval to sell Bt hybrids still boasted a "truthful label" and "higher yield through quality" in order to reassure customers.

The most recent period can be characterized by a disappearance of cotton farmers from the center of anti-GE discourses and shift toward the risks presented to India's consumers via Bt brinjal as a GE food crop. Brinjal ( Solanum melongena) is widely grown by marginal farmers on very small plots of land (one estimate maintains that an average resource poor farmer cultivates one acre of brinjal (Choudhary and Gaur 2009: 63). Despite its popularity among marginal farmers, brinjal can require significant inputs, particularly in terms of insecticides to fend off its most problematic pest, the fruit and shoot borer. On October $14^{\text {th }}, 2009$ the GEAC released Bt brinjal for commercialization but the Ministry of Environment and Forests usurped the decision a day later. Responding to the strong response from certain civil society groups, the Minister Jairam Ramesh indicated he would first conduct a series of consultations with stakeholders in January and February of 2010, prior to any final approval for the crop's release (Staff Reporter 2010). Ramesh's decision to implement a moratorium on Bt brinjal showcased both the strength of civil society's opposition and Ramesh's desire for maintaining transparency in India's GE risk management (Chowdhury and Srivastava 2010: 18). This discursive shift away from farmer's right and GE's environmental risks and towards consumer's rights sets the stage for a strange new tension, whereby farmers' risks (of pesticide exposure) and consumer's risks (from eating Bt brinjal) are inversely related.

The environmental risks of GE farming as articulated by civil society, however, do not easily align with those highlighted by the cotton farmers interviewed for this study; instead an "imagined farmer" appears to motivate much skepticism from activists. The imagined farmer will be misled or coerced by big business, and suffer ruinous crop failure or unknown ailments from working with GE seed. The imagined farmer has no interest in agri-biotech, though increasingly he is compelled to plant Bt cotton because other seed is no

\footnotetext{
14 The NGO informant explained that young girls were often employed in cotton harvesting and processing, and were especially susceptible to health effects from pesticides. Political outcry has lead to requisite training for persons in cotton processing but farm level activities are considerably more difficult to determine (12-5-2009).

15 This toxin is commonly employed by many organic farmers externally as a spray, thus is it the procedures and scientific uncertainties around of genetic engineering itself that proves controversial.
} 
longer available for purchase (Satheesh 2003; Special Correspondent 2003; Shiva and Jalees 2006). Nevertheless, in each of the interviews across seven villages considered here, participants consistently prioritized their reduction in pesticide usage and associated costs as motivators for, and explicit benefits of, switching to Bt cotton. Likewise, when questioned about the risks of cotton farming and how those risks might differ between conventional and $\mathrm{Bt}$ production, a number of pesticide-related concerns were articulated. One respondent from Juradi described sometimes needing up to two or three days of rest after applying the chemicals. He then went on to explain that while he used to spend 5000-6000 rupees (US\$90108) in pesticides over a season, he now spent around 1000 (US\$18). As the participant saw it, this meant "less cost, more profit".

The profitability of Bt cotton has proven contentious and is well studied (Rana 2010; Qaim, Subramanian, Naik and Zilberman 2006; Bennett, Kambhampati, Morse and Ismael 2006; Smale, Zambrano and Cartel 2007). Agricultural economists looking across several countries in the global South have found "Bt cotton's impacts are 'inconclusive"' to date (Smale et al. 2007). However, recent research says that Bt cotton is most impressive in a context where previous loss of the crop due to pests was extensive; alternatively, where there is less dramatic crop loss, the impact of Bt cotton is less significant (Finger et al. 2011). A reliance on increased yield and profitability data as the overriding justification for Bt cotton which is not uncommon among those advocating for its use (as evidenced in the sheer mass of industry, State, and economic-development groups yield studies ${ }^{16}$ ) - may actually overshadow other potential benefits for farmers in those locations where crop loss due to bollworm is less extensive.

Certainly, when asked if there were any benefits to using Bt cotton, farmers routinely pointed to higher yields and increased profits. The range of reported yield increases spanned from five to ten quintals (1 quintal $=c 50 \mathrm{~kg}$ ) per acre planted with conventional cotton, up to ten to twenty quintals of Bt cotton. As one farmer from Bhirgarty rhetorically asked, "what does [a] loss on Bt mean?" indicating that it was something he had yet to see. A medium-scale farmer who grows six acres of cotton alongside other crops pointed out that the less land a farmer has, the more likely that farmer will grow Bt cotton exclusively because it is increasingly viewed as a "ticket to growth". A longitudinal multi-village ethnographic study conducted in Warangal confirms that with the arrival of Bt cotton in the district "...yields rose 18\%, with the greatest increases in the poorest villages..." (Stone 2011: 395).

\section{Unintended effects and unexpected outcomes}

Despite the above incentives to plant Bt cotton, and the satisfaction it enjoys among participants at this time, this agricultural biotechnology was hardly regarded by farmers as a panacea. When asked what their expectations were for Bt cotton, responses were always measured and tended to focus on a decided lack of expectations. Many stated that they would use GE seed as long as it was the "best option", that is, until it either ceases to produce satisfactory results or another more impressive seed comes on the market. As a farmer from Raseetha put it, the bottom line is that: "expenditure must be less, profit must be more". Thus, while widely regarded as the first choice at the moment, Bt cotton is not impossible to fault. In this section I examine some of the unexpected outcomes of the Bt cotton boom in Andhra Pradesh.

From the earliest days of commercialization, farmers and regulators regarded the biosafety of agricultural biotechnology in very different ways. While regulators were charged with the safe release of GE seeds that had properly moved through India's three-tiered regulatory regime (Freeman, Satterfield and Kandlikar 2011), farmers were driven by the urgent need for arresting the loss of their crop. As noted above, the regulatory regime imagined farmers planting a border of non-Bt cotton around the perimeter of the crop; a biosafety precaution intended to reduce the risk of building resistance to $\mathrm{Bt}$ among bollworm (GEAC undated). Seed producers are required to include a separate small package of non-Bt cottonseed with the package of GE seed for these refugia.

When I inquired as to this practice among farmers, one man from Juradi diplomatically stated that, "some use it". However, not one of the 39 participants actually responded by affirming their own use of the refuge seeds. The reasons offered for this ranged from criticism that the seeds produced gangly and unproductive plants, while others explained their land constraints were such that they prefer to plant food crops along the border (e.g. daal) or most commonly, more Bt cotton instead. This disconnect between statemade policy and the quotidian application of agri-biotech presents a regulatory dilemma. To what extent should regulators seek to entertain local notions of risk and biosafety in their policy design? And what happens when the imagined farmer turns out to actually clash with regulatory norms? Set against memories of local men dying from their exposure to toxic pesticides, the urgency of a border crop for safety reasons does not translate well. Nevertheless, the refugia has its purpose and already Monsanto claims to have found evidence of resistance of pink bollworm to Bt (Jebarai 2010), though these conclusions remain contested by India's Central Institute for Cotton Research (MoEF 2010). The quandary here is not so much that the regulations are unreasonable, but rather that they remain removed from farmer's experience of risk and are thus unlikely to be endorsed. If such policies manage to locate themselves within that larger matrix of

16 For example: Qaim, Subramanian and Sadashivappa 2000; Bennett, Morse and Ismael 2006; Qayum and Sakkhari 2005; Huang, Hu, Van Meijl and Van Tongeren 2004; Qaim and Zilberman 2003; Ismael, Bennett and Morse 2002. 
hazards - from the imperatives of poverty to pesticide poisoning - faced by farmers, then a new relevance may yet be found. In fact, recent proposals include a strategy of including the "refuge in a bag" by incorporating the non-Bt seed in the package, rather than keeping it separate to be planted at a border. This socio-ecological compromise also includes bringing the amount of refuge seed to be included from $20 \%$ to a mere 5\% (Chandrashekhar 2011).

Meanwhile, the question of how Bt cotton is affecting insect ecology remains complex, and not yet well understood. The Cry genes in Bt cotton impart toxins for Lepitopteran pests, but not "sucking pests" (Hemipteran) such as the mealy bug, mirid, aphid and whitefly. There is early evidence that these pests may have an affinity for some of the Bt cotton hybrids; however, it is not clear whether this change stems from a reduction in pesticide usage as is being currently observed, because the chronic application of insecticides has also been known to cause such infestations (Stone 2011: 391). In fact the early days of Bt cotton's commercialization saw a difference in insecticide use between Bt cotton and conventional cotton from 2.58 and 6.44 kilograms active ingredient per hectare, respectively in 2004 (SEEP 2010: 1); however, later Bt hybrids susceptible to sucking pests have required a modest, if distressing, increase in insecticide (Kranthi et al. 2011: 19). ${ }^{17}$

The impacts of Bt cotton on farm labor requirements are also compelling and ambiguous. It is commonly argued that farmers using Bt cotton have greater labor requirements, and usually hire local women to help with larger harvests (Qaim et al. 2006). However, the participants in this study often pointed to a reduction in labor requirements as a result of Bt cotton. Farmers in every village explained that the reduced applications of pesticides help account for this, as well as certain attributes of the Bt cotton itself. As one farmer put it, "the women are happy!" This is because they find the Bt hybrids enjoy more uniform boll flowering and bursting than the conventional crop, making the cotton "easier" to collect more quickly and comfortably. Thus, tasks typically assigned to men such as sprayings are reduced, and those tasks typically reserved for women may appear to increase given larger yields, but are also hastened by the ameliorated working conditions. Certainly, the Cry genes cannot be held accountable for such characteristics, as they simply impart Bt toxin to the plant cells. It may be that farmers are inadvertently endorsing particularly wellsuited new hybrids that happen to be genetically engineered. It is also possible that the perception of decreased labor requirements reflects a greater valuation of those male-oriented tasks that have been reduced, alongside an assumption that the women are in fact content. Only one woman was directly interviewed in this research, as she managed her own cotton field - though other women sometimes attended my interviews with male heads of households - so I cannot confirm or refute such attributions. In any case, it is crucial to keep in mind that hired laborers, male or female, are among the most vulnerable in a village economy. If in fact there are fewer employment opportunities as a result of Bt cotton being "easier to grow", this will have important implications for the most marginal households.

Another unanticipated effect explored in the interviews is a change in cropping patterns in all five of the Bt growing villages in Warangal District - also noted in Brookes and Barfoot (2009). These farmers reported that the Bt cotton-growing season was shorter than when they grew conventional hybrids, affording them two extra months, which they now all use to grow an additional crop of maize. This change was not noted in Guntur, perhaps because farmers in that area are already accustomed to alternating their cotton crops with chili - another important cash crop in the region (Venkataramalu, Hanchinal, and Hirevenkanagoudar 2010). While Warangal's farmers were uniformly pleased with the opportunity to cultivate maize, this new cropping pattern may yet prove to affect soil quality or other aspects of the farm ecology, and increase the "pressure of production" on the land (Paulson, Gezon and Watts 2003: 205), warranting further scholarly attention. There is in fact a certain irony in this transformation as well, as it is not uncommon to hear complaints among farmers in Warangal that men from Guntur have depleted their soils from overuse and are moving to Warangal in search of healthier land.

A final point here about the unanticipated, thoroughly overwhelming nature of the Bt cotton seed market: as Stone has documented, there is an exceptional pace with which new Bt cotton hybrids are arriving on the market (Stone 2011). In 2010, there were a total of $780 \mathrm{Bt}$ cotton introductions approved for planting, a full 258 more than the previous year (Clive 2010). Remarkably, this astonishing flood of new seed cannot meet the growing demand (Mukherjee 2011), and in some regions, brief violent outbreaks have arisen as frustrated farmers in long lines for this year's seed were met with limited supply (Bhosale 2011). In many ways, Bt cotton presents a certain paradox in that it offers at once an abundance and a dearth of choice. Stone has carefully detailed the erosion of farmers' opportunities for environmental learning, and how the current melee of seed encourages social learning over environmental testing (Stone 2011: 393). ${ }^{18}$ Certainly, the farmers interviewed for this study highlighted several popular brands (Mallika, Bunny, Rasi, and Tulasi alongside the latest Mahyco hybrids) that were consistently listed as preferred seed despite the much longer

\footnotetext{
17 Thus, the rates in expenditure for insecticide can be traced from their 2001 levels (Rs.10520m or roughly US\$228m) and falling steadily until 2006 (Rs.5790m, or US\$125m) and then increased gradually to Rs.8804 million (US\$191m) by 2010 (Kranthi 2011: 19).

18 Stone describes environmental testing as being "...based on evaluations of pay offs from various practices" while social learning is when "...decisions are based on imitation" (Stone 2011: 393).
} 
list of possibilities. Critics point out the other side of this equation, in that even as farmer have an abundance of $\mathrm{Bt}$ seed options, their choice remains essentially restricted to only Bt options. It has become extremely difficult to purchase non-Bt seed from market sellers any longer.

Lastly, the implications of the dramatic increase in acreage being dedicated to cotton remain to be seen, reflecting that tension between the risks and benefits of this technology; and highlighting important political ecological questions regarding how Bt cotton - as a set of widely adopted new cultivars - may affect local agricultural diversity (Robbins 2004: 215). In the past year, there was an increase of a million hectares in Bt cotton, "from 8.4 million hectares in 2009 to 9.4 million hectares in 2010" (Clive 2010). What were these vast tracts of land previously used for, and what is the significance of the shift for farmers' health, incomes and environments?

\section{Conclusion}

At the heart of the Bt cotton controversy is a conflict over how decisions regarding the technology are made and who gets to make them, as well as how the impacts of, and access to, Bt cotton are managed. This case provides a compelling example of how political debate over GE faming can actually work to overshadow and redirect the significant human and ecological implications of its use. From the reduction of pesticide usage, to the proposed transformation of refugia practices, to the suspension of Bt brinjal, this controversy is shaping the direction of India's agricultural development. The plurality of the vantage points in this conflict necessitate that we look not for the techno-scientific "truths" about Bt cotton, so much as for what Blaikie has called an "opening up of spaces for negotiation between different parties" (Blaikie 1995: 203).

Interviews with farmers in Andhra Pradesh suggest that India's Bt cotton controversy currently excludes several unintended effects and certain missing debates. I suggest this is because both those who advocate for the "biosafe use" of Bt cotton, and those who critique it as having "inherent problems" imagine farmer engagement with the technology in ways that do not always reflect farmers' own practices and priorities. Instead, much like Galt's account of Costa Rican farmers (Galt 2007), we see Bt cotton producers in India negotiating nuances of risk. I have described a broader spectrum wherein GE seed is among a number of hazards, and this framework includes the risks presented by pesticides, which in cotton production are considerable. Given these results, I urge a more expansive assessment of the trade-offs between risks and benefits that farmers are making with GE seed, alongside a closer look at the nuances of their decisionmaking. In this way, the full spectrum of effects and debates caught up in India's Bt cotton controversy may be addressed.

\section{References}

Abhilash, P.C, and N. Singh. 2009. Pesticide use and application: an Indian scenario. Journal of Hazardous Materials 165:1-12.

Gupta, A. 1998. Postcolonial developments: agriculture in the making of modern India. Durham: Duke University Press.

Bag, D. 2000. Pesticides and health risks. Economic and Political Weekly. 35(38):3381-3.

Bennett, R., U. Kambhampati, S. Morse, and Y. Ismael. 2006. Farm-level economic performance of genetically modified cotton in Maharashtra, India. Review of Agricultural Economics 28(1): 59-71.

Bennett, R., S. Morse, and Y. Ismael. 2006. The economic impact of genetically modified cotton on South African smallholders: yield, profit and health effects. Journal of Development Studies 42: 662-77.

Bernauer, T. 2003. Genes, trade, and regulation: the seeds of conflict in food biotechnology. Princeton University Press.

Bhosale, J. 2011. Bt cotton seed shortage to shrink kharif acreage. The Economic Times. http://articles.economictimes.indiatimes.com2011-02-11/news/28540448_1_bt-cotton-seeds-mahycomonsanto-biotech-seed-shortage [Accessed March 13 2011]

Blaikie, P. 1995. Changing environments or changing views? A political ecology for developing countries. Geography. 80(3):203-14.

Blaikie, P.M., and H.C. Brookfield. 1987. Land degradation and society. London: Methuen.

Brookes, G., and P. Barfoot. 2009. Global impact of biotech crops: income and production effects 19962007. AgBioForum 12(2).

Bryant, R.L. 1992. Political ecology: an emerging research agenda in Third-World studies. Political Geography 11:12-36.

Carr, S., and L. Levidow. 2000. Exploring the links between science, risk, uncertainty, and ethics in regulatory controversies about genetically modified crops. Journal of Agricultural and Environmental Ethics 12:29-39. 
Chandrashekhar, G. 2011. India may go for 'refuge in the bag' for Bt cotton. The Hindu Business Line. http://www.thehindubusinessline.com/industry-and-economy/agri-biz/article2447684.ece [Accessed September 15 2011].

Choudhary, B. and K. Gaur. 2009. Brief 38 the development and regulation of Bt Brinjal in India (eggplant/aubergine). Ithaca, NY: The International Service for the Acquisition of Agri-biotech Applications.

Chowdhury, N, and N. Srivastava. 2010. Decision on Bt-Brinjal: legal issues. Economic \& Political Weekly 45:18-22.

Clive, J. 2010. Global status of commercialized biotech/GM crops: 2010. ISAAA Brief No. 42

Finger, R., N. El Benni, T. Kaphengst, C. Evans, S. Herbert, B. Lehmann, S. Morse, and N. Stupak. 2011. A meta analysis on farm-level costs and benefits of GM crops. Sustainability 3:743-62.

Freeman, J., T. Satterfield, and M. Kandlikar. 2011. Agricultural biotechnology and regulatory innovation in India. Science and Public Policy 38:319-31.

Galt, R.E. 2007. Regulatory risk and farmers' caution with pesticides in Costa Rica. Transactions of the Institute of British Geographers 32:377-94.

GEAC, Genetic Engineering Approval Committee. Background note on Bt Cotton development in India. http://moef.nic.in/divisions/csurv/geac/bgnote.htm [Accessed June 12 2011]

Gujar, GT. 2001. Bt cotton in India: too cautious a development. Current Science 80:1253-1253.

Herring, R.J. 2008. Whose numbers count? Probing discrepant evidence on transgenic cotton in the Warangal district of India. International Journal of Multiple Research Approaches 2:145-59.

Herring, R.J. 2009. Persistent narratives: why is the "failure of Bt cotton in India" story still with us? AgBioForum 12:14-22.

Herring, R.J. 2007. Stealth seeds: bioproperty, biosafety, biopolitics. Journal of Development Studies 43:13057.

Huang, J., R. Hu, H. Van Meijl, and F. Van Tongeren. 2004. Biotechnology boosts to crop productivity in China: trade and welfare implications. Journal of Development Economics 75:27-54.

Ismael, Y., R. Bennett, and S. Morse. 2002. Benefits from Bt cotton use by smallholder farmers in South Africa. AgBioForum. 5(1).

Jasanoff, S. 2005. Designs on nature: science and democracy in Europe and the United States. Princeton University Press.

Jebarai, P. 2010. Bt cotton ineffective against pest in parts of Gujarat, admits Monsanto. The Hindu National Section. http://www.hindu.com/2010/03/06/stories/2010030658401400.htm [Accessed July 18 2011]

Kleter, G.A., R. Bhula, K. Bodnaruk, E. Carazo, A.S. Felsot, C.A. Harris, A. Katayama, H.A. Kuiper, K.D. Racke, and B. Rubin. 2007. Altered pesticide use on transgenic crops and the associated general impact from an environmental perspective. Pest Management Science 63:1107-15.

Kranthi, K.R., M.V. Venugopalan, M. Sabesh, and M.S. Yadav. 2011. CICR vision 2030. Indian Council of Agricultural Research.

Mancini, F., A.H.C. Van Bruggen, J.L.S. Jiggins, A.C. Ambatipudi, and H. Murphy. 2005. Acute pesticide poisoning among female and male cotton growers in India. International Journal of Occupational Environmental Health 11:221-32.

Mancini, F. 2006. Impact of integrated pest management farmer field schools on health, farming systems, the environment, and livelihoods of cotton growers in Southern India. PhD dissertation, Biological Systems Farming Group, Wageningen University.

Naranjo, S.E., J.R. Ruberson, H.C. Sharma, L. Wilson, and K. Wu. 2008. The present and future role of insect-resistant genetically modified cotton in IPM. In J. Romeis, A.M. Shelton, and G.G. Kennedy (eds.),

Integration of insect-resistant genetically modified crops within IPM programs. Dordrecht: Springer. 159-94.

MoEF 2010. Inquiry about ineffectiveness of first generation of Bt cotton against pink bollworm. Press Information Bureau Release ID:61476, Indian Ministry of Environment and Forests.

Gupta, A. 1998. Postcolonial developments: agriculture in the making of modern India. Durham: Duke University Press Books.

Mukherjee, B. 2011. Shortage of cotton seeds irks farmers. Times of India. http://articles.timesofindia.indiatimes.com/2011-04-19/india/29446542_1_cotton-seeds-bt-cottonsowing [Accessed August 19 2011]

Murray, D.L. 1994. Cultivating crisis: the human cost of pesticides in Latin America. Austin Texas: University of Texas Press.

Paulson, S., L.L. Gezon, and M. Watts. 2003. Locating the political in political ecology: an introduction. Human Organization 62:205-17.

Qaim, M., A. Subramanian, G. Naik, and D. Zilberman. 2006. Adoption of Bt cotton and impact variability: insights from India. Applied Economic Perspectives and Policy 28(1): 48-58 
Qaim, M., A. Subramanian, and P. Sadashivappa. 2009. Commercialized GM crops and yield. Nature Biotechnology 27:803-4.

Qaim, M., and D. Zilberman. 2003. Yield effects of genetically modified crops in developing countries. Science 299:900-902.

Qayum, A, and K Sakkhari. 2005. Bt Cotton in Andhra Pradesh. A three-year assessment. The first ever sustained independent scientific study on Bt cotton in India. Deccan Development Society, Andhra Pradesh Coalition in Defence of Diversity, \& Permaculture Association of India.

Qayum, A., and K. Sakkhari. 2002. Did Bt cotton save farmers in Warangal? A season long impact study of Bt cotton Kharif. Zaheerabad: Deccan Development Society.

Rana, M.A. 2010. Formalising the informal: the commercialisation of GM cotton in Pakistan. PhD thesis, Melbourne School of Land and Environment. University of Melbourne.

Rao, C.K. 2007. Why do cattle die eating Bt cotton plants only in the Telengana region of Andhra Pradesh in India? Foundation for Biotechnology Awareness and Education Bangalore, India. http://www. plantbiotechnology. org. in/issues. html [Accessed August 18 2011]

RFSTE, Research Foundation for Science, Technology and Ecology. 2002. Failure of Bt cotton in India. http://www.biotech-info.net/bt_failure.html [Accessed March 13 2011]

Robbins, P. 2004. Political ecology: a critical introduction. $1^{\text {st }}$ edition. Oxford: Blackwell.

Rose, N. 1999. Powers of freedom: reframing political thought. Cambridge University Press.

Sahai, S. 2005. The science of Bt cotton failure in India. The Hindu Opinion - News Analysis 29 August.

Satheesh, P V. 2003. Finally I have seen Bt cotton. Seedling GRAIN. www.grain.org/seedling/seed-03-01-1en.cfm [Accessed March 23 2011]

SEEP Expert Panel on Social, Environmental and Economic Performace of Cotton Production. 2010. Factors influencing the use of pesticides in cotton in India. August.

Sengupta, A. 2011. Mr PM, what's in our food? Bangalore Mirror. Views Section 28 August. ttp://www.bangaloremirror.com/article/36/2011082820110828195114819573162f1/Mr-PMwhat\%E2\%80\%99s-in-our-food-.html [Accessed August 28 2011]

Sharma, Devinder. 2010. Bt brinjal: good sense prevails over bad science. Ground Reality.10 February. http://devinder-sharma.blogspot.com/2010/02/bt-brinjal-good-sense-prevails-over-bad.html [Accessed 28 August 2011]

Shetty, PK. 2004. Socio-ecological implications of pesticide use in India. Economic and Political Weekly 39 (49): 5261-5267.

Shiva, V. 2000. Stolen harvest: the hijacking of the global food supply. Gardners Books.

Shiva, V., A. Emani, and A.H. Jafri. 1999. Globalisation and threat to seed security: case of transgenic cotton trials in India. Economic and Political Weekly 34(10/11): 601-613.

Shiva, V. and K. Jalees. 2006. Seeds of suicide: the ccological and human costs of seed monopolies and globalization of agriculture. New Delhi: Navdanya.

Smale, M., P. Zambrano, and M. Cartel. 2007. Bales and balance: a review of the methods used to assess the economic impact of Bt cotton on farmers in developing economies. AgBioForum. 9(3).

Special Correspondent. 2003. Bt cotton farmers suffered losses, says Greenpeace. The Hindu. 17 April. http://hindu.com/2003/04/17/stories/2003041703430400.htm [Accessed March 13 2011]

Sri, I. Aruna; Rao, V. Ramasubba; Sekhar, P. Raja; Chalam, M.S.V. 2010. Taxonomic studies on different Lepidopteran caterpillars on cotton, chilli and pulses. Annals of Plant Protection Sciences. 18(1) 104-7.

Staff Reporter. 2010. Chaos, deep divisions at consultation on Bt brinjal. The Hindu National News. 6 February. http://www.thehindu.com/news/national/article102036.ece [Accessed February 6, 2010].

Stone, G.D. 2002. Both sides now: fallacies in the genetic-modification wars, implications for developing countries, and anthropological perspectives. Current Anthropology 43:611-30.

Stone, G.D. 2007. Agricultural deskilling and the spread of genetically modified cotton in Warangal. Current Anthropology 48:67-103.

Stone, G.D. 2011. Field versus farm in Warangal: Bt cotton, higher yields, and large questions. World Development 39(3): 387-98.

Venkataramalu, M, S.N Hanchinal, and L.V Hirevenkanagoudar. 2010. Adoption of improved cultivation practices among chili growers. Karnataka Journal of Agricultural Sciences 23:722-5. 


\begin{abstract}
India's encounter with genetically engineered Bt cotton has been a contested one, and one that has rarely conformed to expectations. I argue that two primary vantage points on the question of agricultural biotechnology - those advocating the "biosafe use" of Bt cotton or those who insist it involves "inherent problems" - frequently anticipate an "imagined farmer" in incomplete and sometimes plainly incorrect ways. Thus, there is more to the Bt cotton debate than has been considered to date. Drawing from qualitative interviews with cotton farmers in two regions of Andhra Pradesh, I call attention to the unintended effects of widespread Bt cotton cultivation and debates missing from this controversy. Misconstrual of the "imagined farmer" has edged out civil society's acknowledgement of farmers' negotiation of the (immediate and physical) risks of pesticide use as contrasted with those (more abstracted and unknown) of genetically engineered seed. Bt cotton's advocates, on the other hand, seldom address the unintended effects of its widespread use, including potentially reduced labor opportunities for the most marginal rural laborers. In conclusion, I urge a more expansive assessment of the trade-offs between risks and benefits that farmers make regarding $\mathrm{Bt}$ cotton, alongside a closer look at the nuances of their decision-making. Framing agribiotech risk as a matter of manageable (or inherently problematic) "biosafety" does not resonate with farmers using a broader concept of health and environmental safety threatened by heavy pesticide usage.
\end{abstract}

Keywords: Bt cotton, political ecology, genetic engineering risk, pesticides, India

\title{
Résumé
}

Coton Bt, génétiquement modifié, a été contestée et a rarement conforme à expectations en Inde. Ils sont deux points de vue principaux sur la question de la biotechnologie agricole - ceux qui préconisent l' 'utilisation biosécuritaire' du coton Bt, ou ceux qui insistent qu'il s'agit de problèmes inhérents. Les deux anticiper une «agriculteur imaginée» d'une manière qui sont incomplètes et parfois manifestement erronée. Il est plus au débat que le coton Bt a été pris en considération. À partir d'entretiens qualitatifs avec les producteurs de coton dans deux régions de l'Andhra Pradesh, j'attire l'attention sur les effets non intentionnels de la culture du coton Bt répandue et les débats qui manquent dans cette controverse. Des erreurs d'interprétation de la «agriculteur imaginaire» ont devancent la reconnaissance de la société civile de la négociation des agriculteurs des risques (immédiat et physique) de l'utilisation des pesticides, en contraste avec ceux (plus abstraites et inconnues) des semences génétiquement modifiées. Les défenseurs du coton Bt, sur un autre côté, s'addresse rarement les effets non intentionnels de l'utilisation généralisée, y compris les possibilités d'emploi potentiellement réduits pour les travailleurs les plus rurales marginales. En conclusion, je demande une évaluation plus large de compromis entre les risques et les avantages que les agriculteurs font ce qui concerne le coton Bt, aux côtés de plus près les nuances de leur prise de décision. L'encadrement la risque agro-biotechnologie comme une question de gérer (ou problématique en soi) "biosécurité" ne résonne pas avec les agriculteurs utilisant un concept plus large de la sécurité sanitaire et environnementale menacée par l'utilisation des pesticides lourde.

Mots-clés: coton Bt, l'écologie politique, le risque du génie génétique, les pesticides, l'Inde

\section{Resumen}

El encuentro entre India con el algodón genéticamente modificado (Bt) ha sido un tema cuestionable y que poco ha cumplido con las expectativas. Yo sostengo que los dos principales puntos de vista sobre la cuestión de la biotecnología agrícola- el de aquellos que defienden el "uso bioseguro" del algodón Bt o el de quienes insisten que esto conlleva "problemas inherentes"- prevén frecuentemente de manera incompleta y muchas veces simplemente incorrecta "un "agricultor imaginario". Por eso, en el debate del algodón Bt existe más de que lo que se ha considerado hasta hoy. En base a las entrevistas cualitativas con algodoneros agrícolas en dos regiones de Andhra Pradesh, señalo los efectos no deseados del cultivo generalizado del algodón Bt y los debates que faltan de esta controversia. La interpretación errónea del "agricultor imaginario" ha logrado por parte de la sociedad civil, el reconocimiento de la negociación de los agricultores sobre los riesgos (inmediatos y físicos) del uso de pesticidas en comparación con aquellos (más abstractos y desconocidos) de la semilla genéticamente modificada. Los defensores del algodón Bt, por otra parte, raras veces señalan los efectos no deseados de su uso extenso, incluyendo la posible disminución de oportunidades de trabajo para los trabajadores rurales más marginados. En conclusión, exhorto a una evaluación más comunicativa de los intercambios que hacen los agricultores entre riesgos y beneficios respecto al algodón Bt, junto con una revisión más rigurosa de los matices de su toma de decisiones. Bajo el marco de que el riesgo agrícolabiotécnico como asunto de "bioseguridad" manejable (o intrínsecamente problemático) no hace eco en los agricultores que utilizan un concepto más amplio de salud y seguridad ambiental amenazado por el uso abundante de pesticidas.

Palabras clave: El algodón Bt, ecología política, riesgos de la ingeniería genética, pesticidas, India 